\title{
EVALUATING SHRUB-STEPPE HABITAT QUALITY USING THE PYGMY RABBIT (BRACHYLAGUS IDAHOENSIS) AS AN INDICATOR SPECIES
}

\author{
KATHERINE L. PARKER DEPARTMENT OF ZOOLOGY AND PHYSIOLOGY \\ UNIVERSITY OF WYOMING $\bullet$ LARAMIE
}

\section{$\rightarrow$ OVERVIEW}

The structurally-complex stands of sagebrush that are important as wildlife habitat are rapidly disappearing because of conversion to irrigated agriculture, spraying and brush removal treatments, wildfires, and intensive grazing. These sagebrushdominated steppe habitats support a variety of wildlife species. For some, they serve as year-round home ranges; for others, as critical winter or transitional habitats. The pygmy rabbit (Brachylagus idahoensis) is an example of an extreme specialist, solely restricted in its distribution to such sagebrushdominated steppe habitats, and typically associated with dense stands of big sage (Artemesia tridentata). Most known populations now are declining.

The basis or extent of the shrub-steppe habitat dependency by pygmy rabbits is not fully understood. Sagebrush comprises a major portion of the diet, ranging from $51 \%$ in summer to $99 \%$ in winter (Green and Flinders 1980). Tall stands of sage provide a dense "canopy" cover for protection from raptorial predators and a dense sage "understory" structure that is important for protection from ground predators. Pygmy rabbits are very slow compared with other leporids and therefore are vulnerable in open habitats. Big sage also may provide an improved microclimate space and ease in food acquisition by contributing to the formation of snow drifts in winter for better ground insulation over burrows, and for subnivean trails, which the animals use for access to food between sagebrush plants (Bradfield 1975). The thermoregulatory capabilities of this species have not been determined. Furthermore, although the location of nests is unknown, a dense sage base may provide necessary thermoregulatory and hiding cover for young animals.

Because pygmy rabbits are typically found in low numbers with small spatial requirements, destruction and fragmentation of sagebrush grasslands may drastically affect their distribution, abundance, and dispersal abilities. Habitat alterations via intensive grazing may limit the value of sagebrush communities to pygmy rabbits by changing plant species and structural form. In particular, livestock that are attempting to reach grasses at the base and perimeter of sagebrush can break down the understory of sagebrush plants, resulting in "pedestalling" or tree forms. Dense stands of sagebrush plants without a dense understory do not appear to support pygmy rabbits, presumably because of the need for cover, easy access to food, and/or nest protection. Because this species has small but specific spatial requirements, the isolation of small populations make it susceptible to rapid declines and possible extirpation. Also because of this extreme dependency on sagebrush-dominated habitats, the pygmy rabbit may serve as an indicator of the health and balance of the sagebrush ecosystem.

\section{- OBJECTIVES}

The objectives of this research are summarized as follows: 
1. Investigate the relationships between the structural/compositional features of the shrub-steppe habitat, and the winter home range, habitat use, and activity patterns of pygmy rabbits.

2. Determine microhabitat selection by pygmy rabbits during winter in relation to microclimate and vegetation structure.

3. Define large scale habitat features that are characteristic of areas inhabited by pygmy' rabbits.

\section{$\checkmark \quad$ METHODS}

This study will begin in January 1993, with emphasis on understanding how such a small species (400 grams) that does not hibernate or significantly deposit fat, manages to survive in areas of extreme environmental temperatures, consuming primarily sagebrush. Graduate student, Todd E. Katzner, is currently finalizing the design for this research and will complete the study to obtain a Master's degree in the Department of Zoology and Physiology at the University of Wyoming.

Two research sites were selected in September 1992. The primary site is located near the Historic Quarry Trail in Fossil Butte National Monument, $16 \mathrm{~km}$ west of Kemmerer, Lincoln County, Wyoming. Preliminary observations suggest that this ungrazed area supports a healthy population of pygmy rabbits. The second site is $14.5 \mathrm{~km}$ west of the Monument along Collet Creek. Vegetation at this site appears trampled or is entirely absent from recent grazing; pygmy rabbit sign is much reduced. The general landscape at both sites can be characterized as high, cold, sage-dominated desert. In October 1992, a grid system $1 \mathrm{~km}$ x $0.35 \mathrm{~km}$ was installed at each site for use during radiotelemetry monitoring and habitat assessment. This system consists of twenty color-coded transects perpendicular to a baseline with metal stakes positioned every 50 $\mathrm{m}$, resulting in 0.25 ha units.

Eight adult pygmy rabbits will be captured in January in each population and equipped with radiocollars. Animals will be intensely monitored from radiotelemetric traces and visual observations to determine basic life requisites such as home range size and activity budgets. Meteorological variables (air temperature, wind, solar and thermal radiation) will be simultaneously measured in open and sagecovered microenvironments; these data will be used to assess the impacts of microclimate on activity patterns and provide indications of thermal tolerance. Vegetation will be quantified in terms of food quality (based on laboratory analyses of energy, protein, and fat content), shrub density and height, and community structural appearance to assess the effects of grazing practices and habitat alterations. Shrub-steppe characteristics (including vertical structure, composition, vegetation pattern, and topography) that are identified as important to pygmy rabbits will be contrasted to areas that do not support pygmy rabbits and compared to the documented habitat requirements for other sagebrush/grassland species.

\section{$\checkmark \quad$ ANTICIPATED BENEFITS}

Almost no work has been conducted on pygmy rabbits, and their basic biology is poorly understood. This research will clarify some of the ecological/physiological adaptations of the world's smallest leporid and define its obligate shrub-steppe association. Because pygmy rabbits are entirely dependent on sagebrush communities for survival, they may serve as an effective means of environmental surveillance in shrub-steppe grasslands, and as an ecological indictor to better assess the loss of wildlife habitat resulting from conflicting land uses.

The pygmy rabbit appears to be regulated by overgrazing and alterations of its natural habitat, is likely very sensitive to habitat fragmentation (landscape patterns), and should be relatively easy to work with from a demographic perspective. Our study will draw attention to the qualities of structurally-complex stands of sagebrush that may be important in the distribution and abundance of other wildlife species. It also has implications for the management of state and federal lands, and will contribute to landscape planning decisions that incorporate vast expanses of sagebrush-dominated steppe habitats. 


\section{$\checkmark \quad$ LITERATURE CITED}

Bradfield, T. 1975. On the behavior and ecology of the pygmy rabbit Sylvilagus idahoensis. M. S. Thesis, Idaho State Univ., Pocatello. 43 pp.
Green, J. S., and J. T. Flinders. 1980b. Habitat and dietary relationships of the pygmy rabbit. J. Range Manage. 33:136-142. 